\title{
Hydrothermic treatment in the soft rot control in potatoes and their changes in the post-harvest characteristics
}

\author{
Rhayf Eduardo Rodrigues ${ }^{1}$, Marilia Assis dos Santos ${ }^{2}$, Clarice Aparecida Megguer ${ }^{1}$, Heitor da Silva Silveira ${ }^{3}$, \\ Raphaela Felippe ${ }^{1}$ \\ ${ }^{1}$ Instituto Federal Goiano, Campus Morrinhos, Morrinhos, GO. ${ }^{2}$ Instituto Federal de Rondônia, Campus Jaru, RO. \\ ${ }^{3}$ Bunge-Agronegócio
}

\begin{abstract}
Several strategies have been studied to control soft rot in potatoes, but in many cases they are based on methods that, even though they present promising results, they require a high investment, besides the difficulty of being applied in large scales, which makes the use of hydrothermal treatment an interesting alternative. The aim of this study was to evaluate the influence of different immersion temperatures used in the hydrothermal treatment on the post-harvest quality of the treated tubers. The experiment was conducted as a completely randomized design with five immersion temperatures: control, 40, 50, 60 and 70 ${ }^{\circ} \mathrm{C}$, and five storage periods: $0,5,10,15$ and 20 days. Post-harvest quality determination was performed by evaluating pulp firmness, $\mathrm{pH}$, titratable acidity (\% citric acid) and soluble solids content ( ${ }^{\circ}$ Brix) Throughout the storage period the tubers with symptoms of soft rot were counted and discarded. The immersion temperature caused changes in the parameters of pulp firmness, titratable acidity and soluble solids content. Tubers submitted to immersion temperature of $70{ }^{\circ} \mathrm{C}$ were all eliminated on the 5th day of evaluation. The immersion of potatoes at $40{ }^{\circ} \mathrm{C}$ was the most efficient in reducing the accurrance of soft rot, while maintaining the physical-chemical characteristics of the treated tubers during the storage period of 20 days.
\end{abstract}

Keywords: agata; physical treatment; Pectobacterium; Solanum tuberosum L.

\section{Tratamento hidrotérmico no controle da podridão-mole em batatas e suas alterações nas características pós-colheita}

\begin{abstract}
Resumo
Diversas estratégias tem sido alvos de estudos para controle de podridão-mole em batatas, porém em muitos casos baseiam em métodos que mesmo apresentando resultados promissores, demandam um alto investimento, além da dificuldade de serem aplicados em grandes volumes, o que torna o emprego do tratamento hidrotérmico uma alternativa interessante. Objetivou-se com este estudo avaliar a influência de diferentes temperaturas de imersão empregadas no tratamento hidrotérmico na qualidade pós-colheita dos tubérculos tratados. $O$ experimento foi conduzido seguindo um delineamento inteiramente casualizado com cinco temperaturas de imersão: controle, $40,50,60$ e $70^{\circ} \mathrm{C}$, e cinco períodos de armazenamento: 0,5 , 10, 15 e 20 dias. A determinação da qualidade pós-colheita foi realizada por meio da avaliação de firmeza de polpa, pH, acidez titulável (\% ácido cítrico) e teor de sólidos solúveis ( $\left.{ }^{\circ} B r i x\right)$. Ao longo do período de armazenamento os tubérculos com sintomas de podridão-mole foram contabilizados e descartados. A temperatura de imersão causou modificações nos parâmetros de firmeza de polpa, acidez titulável e no teor de sólidos solúveis. Os tubérculos submetidos a temperatura de imersão de $70{ }^{\circ} \mathrm{C}$ foram todos eliminados no $5^{\circ}$ dia de avaliação. A imersão de batatas na temperatura de $40^{\circ} \mathrm{C}$ foi a que se mostrou mais eficiente em reduzir o aparecimento de podridão mole, mantendo ainda as características físico-químicas dos tubérculos tratados pelo período de armazenamento de 20 dias.
\end{abstract}

Palavras-chave: ágata; Pectobacterium; Solanum tuberosum L.; tratamento físico 


\section{Introduction}

Potato (Solanum tuberosum L.) is one of the world's oldest crops and ranks fourth among the world's most important food crops, behind only wheat and rice (CHANG et al., 2011; FAO, 2011). This importance is due to potatoes being a fairly common, accessible and nutritious vegetable, with a high energy value, in addition to being rich in vitamins and minerals (LOVAT et al., 2015; ABBA, 2017). In the last decade the Brazilian production had an expressive increase in production with 3.867 .681 tons produced in $2015,21 \%$ the world-wide productivity (IBGE, 2016).

The potato crops is, however, affected by a large number of phytopathogens, resulting in large losses in production, in addition to directly influence the postharvest quality of tubers. Among the pathogens that affect potato in the postharvest period, soft rot stands out due to its destructive potential causing significant economic losses (ZAMBOLIM, 2011; WALLERON et al., 2014). Soft rot is a disease caused by pectolytic bacterias, mainly of the genus Pectobacterium, and may occur at any stage of postharvest handling (MANTSEBO et al., 2014; CZAJKOWSKI et al., 2015).

Several strategies have been the target of studies for the soft rot control in potatoes. These control methods range from the pre-planting stage to the selection of healthy seeds and the cleaning of the machinery to be used, as well as methods aimed at eliminating the pathogen in the cleaning phase of the harvested tuber (CZAJKOWSKI et al., 2011). Several methods, even with promising results in disease control, like the ultraviolet radiation, needs a high investment, besides the difficulty of being applied in large scale (USALL et al.,2016; DIAS et al., 2017). Chlorine and antibiotic based products have already been employed in the attempt to eliminate these pathogens, though they are no longer recommended because of environmental concerns and human health (JESS et al., 2014).

Due to these concerns, the search for physical techniques that cause low environmental impact and are also effective in the control of pathogens has grown around the world. Among these techniques is the hydrothermal treatment, which has the main advantage of not presenting risks to human health. The hydrothermal treatment consists of immersing the product in water at temperatures ranging from 40 to $60{ }^{\circ} \mathrm{C}$ (USALL et al., 2016). However, there is a need to evaluate the influence of temperature used not only on pathogen control, but also on the post-harvest quality of the treated tubers. Therefore, the aim of this study was to evaluate the influence of different immersion temperatures employed in the hydrothermal treatment in the post-harvest quality of treated tubers.

\section{Material and Methods}

Potatoes, cultivar Agata were acquired in the Supply Central State (CEASA), Goiânia, Goiás and taken to the PostHarvest Laboratory of IF Goiano Campus Morrinhos (17 48'48,93" S; $49^{\circ} 12^{\prime} 15,56^{\prime \prime} \mathrm{O} ; 753 \mathrm{~m}$ of altitude), where they were classified and selected for absence of lesions, color and uniformity of size.

The experiment was conducted following a completely randomized design with four treatments (immersion temperatures) and four replicates with split plots in time. The potatoes were inoculated using $10 \mu \mathrm{L}$ of bacterial suspension in concentration of $1 \times 10^{9}$ U.F.C. $\mathrm{mL}^{-1}$ (O.D. $540=0,3$ ) reisolated from another tuber with severe symptoms of soft rot. The tubers were then subjected for 1 minute to four immersion temperatures (control, 40, 50, 60 and $\left.70 \mathrm{C}^{\circ}\right)$, and five storage periods $(0,5,10,15,20$ days). For immersion of the potatoes were used metal baskets with water were use for immersion of the potatoes so that all potatoes were submerged. During the imposition of the treatments the temperature was monitored using a digital thermometer and the exposure measured time with a digital timer. After the imposition of the treatments, the tubers were taken to the PostHarvest Laboratory of Instituto Federal Goiano - Campus Morrinhos where they were stored on the benches. During the storage period, the potatoes were kept at a temperature of $28^{\circ} \mathrm{C}$ and high relative humidity.

The determination of post-harvest quality was carried out by means of visual evaluations and by the evaluation of pulp firmness, $\mathrm{pH}$, titratable acidity (\% citric acid) and soluble solids content ( ${ }^{\circ}$ Brix). The evaluations were performed on the day of imposition of the treatments, and at $5,10,15$ and 20 days of storage. The pulp firmness was obtained by the applanation method, and its values expressed in Kgf (CALBO; NERY, 1995). The extract obtaining for determination of $\mathrm{pH}$, titratable acidity and 
soluble solids content was perfomed by a domestic food centrifuge. The $\mathrm{pH}$ values were obtained using a digital bench pHmetre (mPA210, Tecnopon, Piracicaba, Brasil), previously calibrated with $\mathrm{pH} 4.0$ and 7.0 buffer solution. The acidity was determined by neutralization titration method (AOAC, 2010) and soluble solids was obtained by adding 3 drops of the extract under the prism of a portable refractometer (ATAGO, Japão).

The incidence of soft rot was determined from visual form, from the moment that the characteristic symptoms were noticed, such as softening and bacterial exudation. The potatoes that presented the symptoms of soft rot were counted and discarded.

The data were submitted to the Cochran (Homoscedasticity) and Lilliefors (normal data) tests. Then, the data were submitted to analysis of variance and the averages were compared by the Tukey test at $5 \%$ probability.

\section{Results and Discussion}

The effective control of soft rot in response to immersion temperature was evaluated by the percentage of total tubers discarded at the end of storage days due to the appearance of symptoms characteristic of soft rot (Table 1). Tubers submitted at $40{ }^{\circ} \mathrm{C}$ were the ones that had the least symptoms, while those submitted to a temperature of $70{ }^{\circ} \mathrm{C}$ were all discarded at 10 days of evaluation (Table 1 ).

Table 1. Percentage of tubers eliminated as a result of the occurrence of soft rot in different immersion temperatures.

\begin{tabular}{cc}
\hline Temperature $\left({ }^{\circ} \mathrm{C}\right)$ & \% Discarded \\
\hline Control & 31,25 \\
40 & 12,50 \\
50 & 31,25 \\
60 & 18,75 \\
70 & 100,00 \\
\hline
\end{tabular}

Pulp firmness at day zero did not differ between control treatments, 40,50 and $70{ }^{\circ} \mathrm{C}$, with values around $8 \mathrm{kgf}$. The tubers submitted to a temperature of $50{ }^{\circ} \mathrm{C}$ differed from the other treatments, with averages around $5 \mathrm{kgf}$ (Figure 1). At 5 and 10 days of storage the control treatments and $40{ }^{\circ} \mathrm{C}$ had higher firmness values of pulp. At 15 days, the firmness values of the treatments 40 and $50{ }^{\circ} \mathrm{C}$ were higher than the others by the Tukey test at $5 \%$ probability. In the 20th day of storage the tubers submitted to a temperature of $40{ }^{\circ} \mathrm{C}$ presented higher values than the others. Pulp firmness values decreased over the storage period at all immersion temperatures. In the treatment of $40{ }^{\circ} \mathrm{C}$ the reduction was around $22 \%$, while the other treatments this reduction was higher than $30 \%$ (Figure 1). 
Figure 1: Pulp firmness of potato tubers in response to different immersion temperatures over 20 days of storage. Treatments followed by the same lowercase letters in each day of storage do not differ from each other by the Tukey test at $5 \%$ probability. Capital letters compare the treatments between the days.

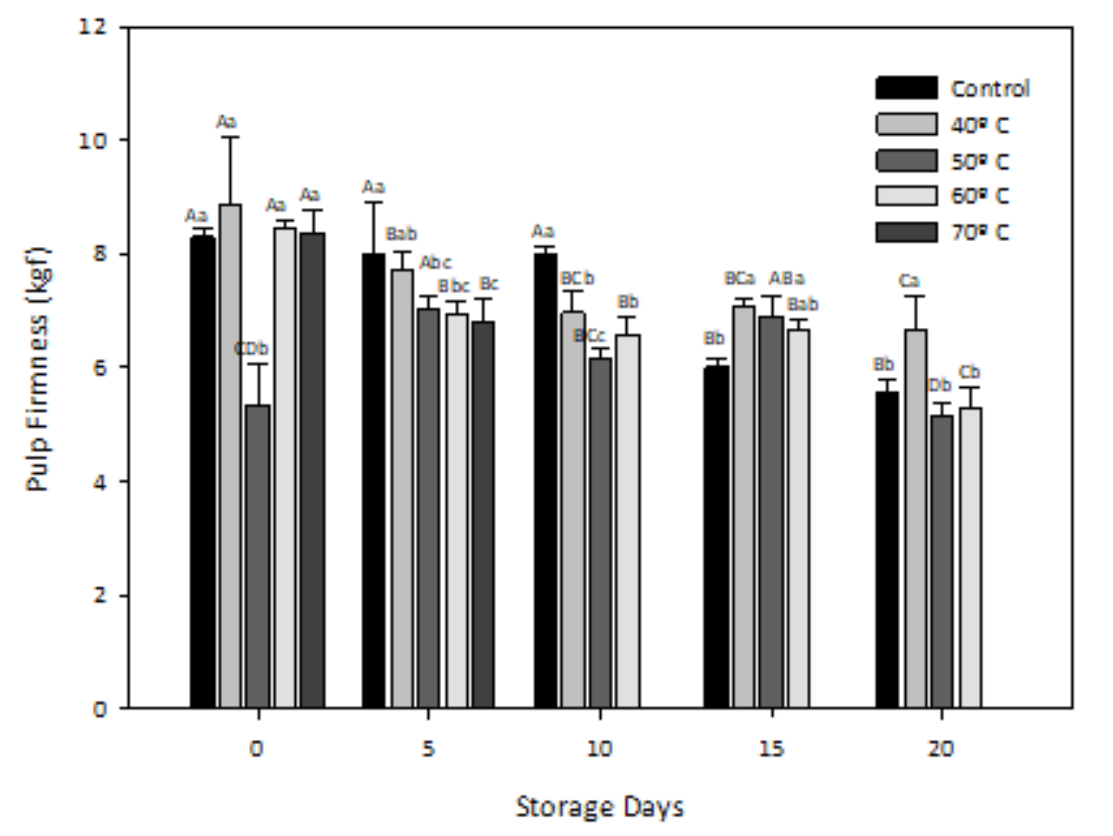

Soluble solids contents at day zero and at day 20 differed by Tukey test at $5 \%$ probability, however on the other days there was no significant difference. On the last day of evaluation, the tubers submitted to a temperature of $60{ }^{\circ} \mathrm{C}$ presented a mean of soluble solids higher than the others. During the storage period the soluble solids contents increased $15 \%$ in relation to day zero (Figure 2 ).

Figura 2: Soluble Solid ( ${ }^{\circ}$ BRIX) of potato tubers in response to different immersion temperatures over 20 days of storage. Treatments followed by the same lowercase letters in each day of storage do not differ from each other by the Tukey test at $5 \%$ probability. Capital letters compare the treatments between the days.

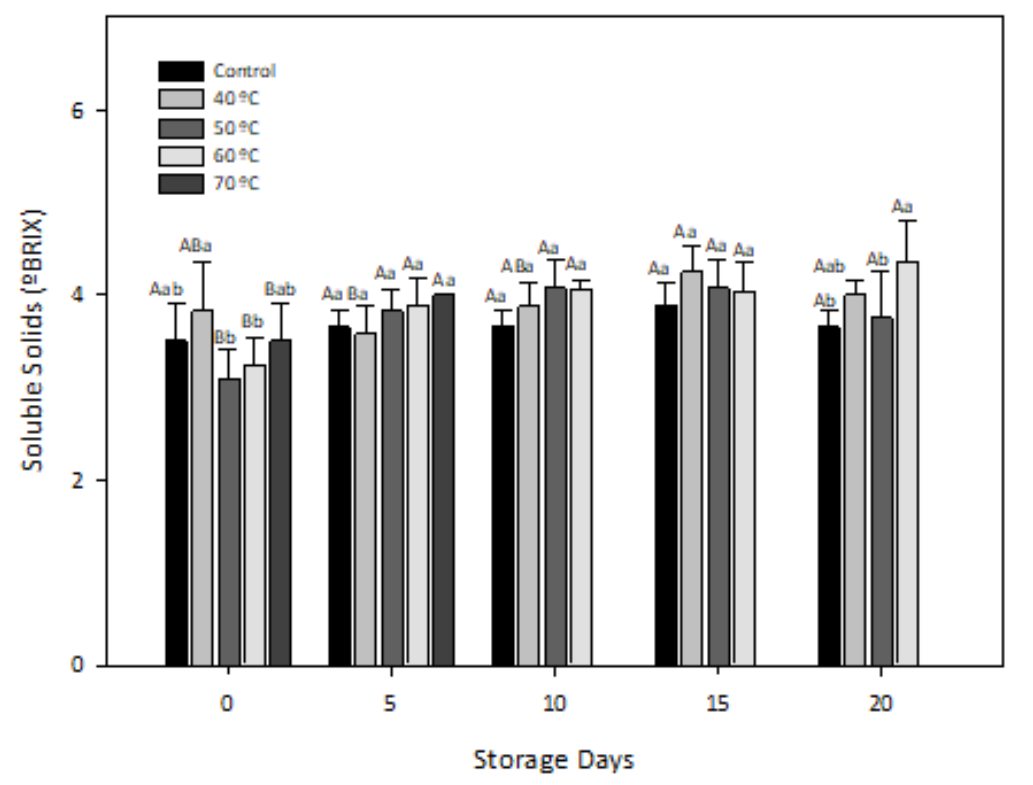


On the first day of evaluation, the values of titratable acidity of the tubers submitted to the temperatures of $40,50,60$ and $70{ }^{\circ} \mathrm{C}$ had higher values than the control for titratable acidity, but did not differ among themselves by Tukey test at $5 \%$ probability (Figure 3 ). In the 5 th day of storage the treatment of $40{ }^{\circ} \mathrm{C}$ was different from the others, with higher values of acidity while the treatment of $60{ }^{\circ} \mathrm{C}$ presented lower averages and acidity. On day 10 and evaluation the treatment of $40{ }^{\circ} \mathrm{C}$ presented higher mean values of acidity than the others, whereas on the 15 th day the treatments of $50{ }^{\circ} \mathrm{C}$ and $60{ }^{\circ} \mathrm{C}$ were higher (Figure 3 ).

Figura 3: Titratable acidity of potato tubers in response to different immersion temperatures over 20 days of storage. Treatments followed by the same lowercase letters in each day of storage do not differ from each other by the Tukey test at $5 \%$ probability. Capital letters compare the treatments between the days.

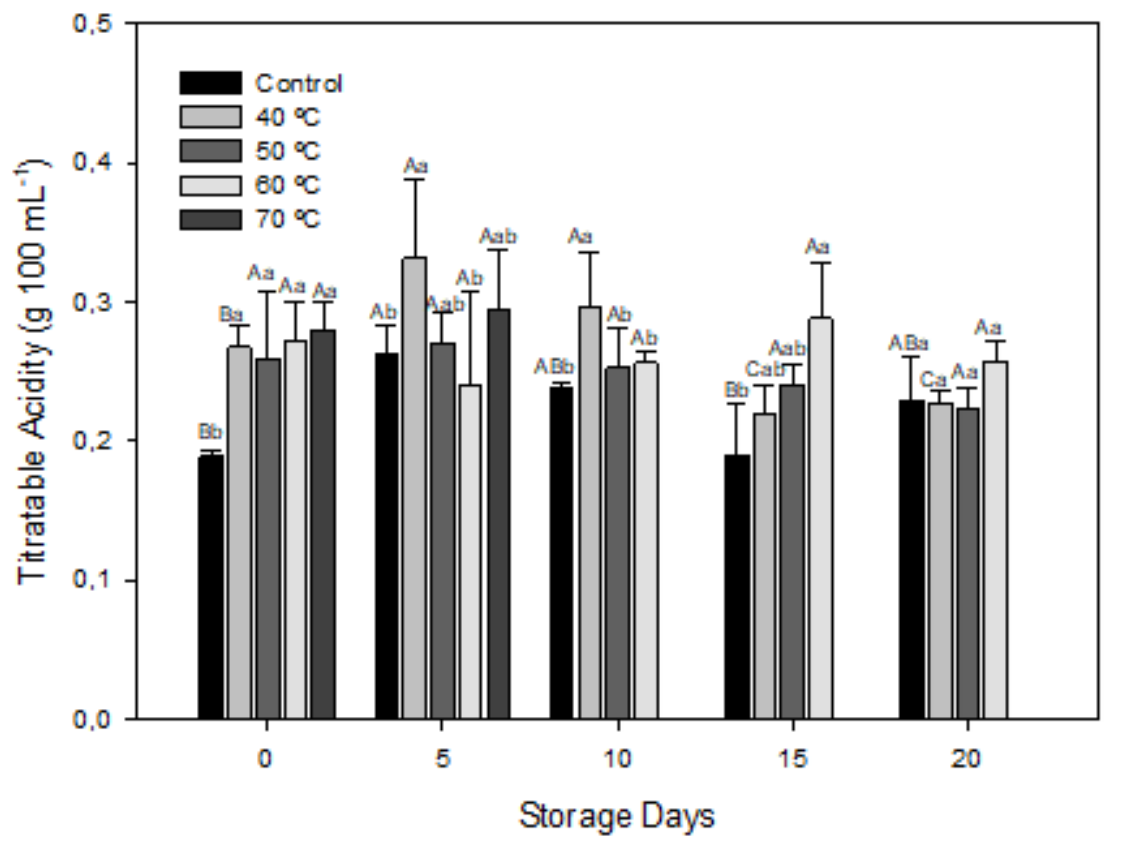

Regarding the $\mathrm{pH}$ values, there was no difference between treatments on each day of evaluation, with a small variation over the storage period. 
Figura 4: $\mathrm{PH}$ values of potato tubers in response to different immersion temperatures over 20 days of storage. Treatments followed by the same lowercase letters in each day of storage do not differ from each other by the Tukey test at $5 \%$ probability. Capital letters compare the treatments between the days.

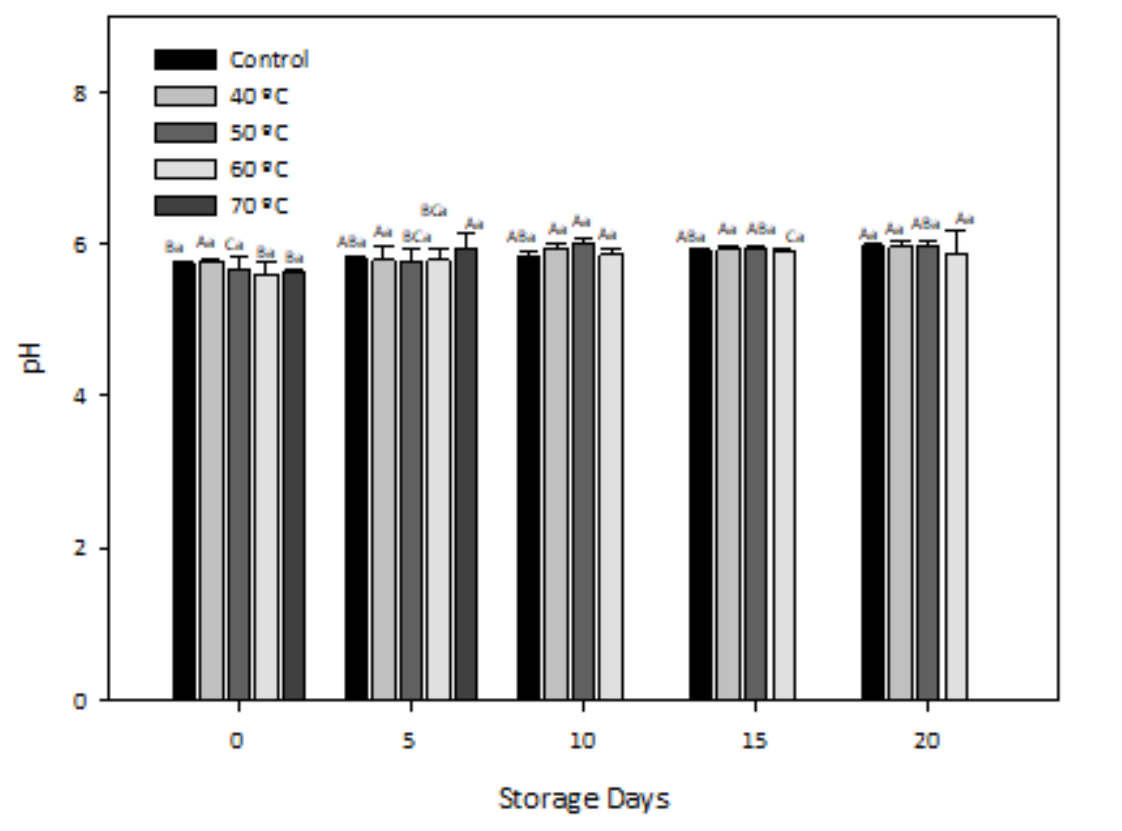

Tubers submitted to a $70{ }^{\circ} \mathrm{C}$ immersion temperature were discarded after the 5 th day of evaluation due to the appearance of severe symptoms of soft rot and senescence. The senescence process in the tubers submitted to this temperature was accelerated due to physiological disturbances caused by the high temperature, mainly the degradation of cell wall compounds, which favored the attack of the bacteria. Moreover, the increase in temperature is directly related to the breathing process, which leads to the consumption of reserves accelerating the process of senescence.

Firmness is a parameter of extreme importance in potatoes because it is one of the main characteristics evaluated by the consumer when buying the product in natura in the shelves. On the 5th and 10th evaluation days, the control treatment had higher pulp firmness values, followed by the treatment of $40{ }^{\circ} \mathrm{C}$. This reduction in firmness is explained by the degradation of the cell wall compounds of the tubers, making it softer. The same was observed by LUNARDI et al. (2003), working on the control of white rot in apples, it was observed that in the first day of evaluation, the control treatment presented greater firmness of pulp than the other treatments submitted to the hydrothermal treatment.
At 15 days of storage the control treatment had lower pulp firmness in relation to the others, as a function of disease progression. The treatment $40{ }^{\circ} \mathrm{C}$ and $50{ }^{\circ} \mathrm{C}$ better preserved the firmness of the pulp in order to better control the severity of the soft rot until that point of the evaluation period. However, on the 20th day of the evaluation only the $40{ }^{\circ} \mathrm{C}$ treatment was maintained with higher firmness values due to the physiological disturbances caused by the other temperatures, favoring the appearance of soft rot along the storage time.

Soluble solids values increased over the storage period. This increase is due to the conversion of starch to sugars by the respiratory process. On the last day of evaluation the treatment of $60^{\circ} \mathrm{C}$ presented values higher than the others, due to the higher level of tuber degradation, due to the probable increase in respiration caused by bacterial infection.

On the first day of evaluation, the control had lower acid values than the treatments submitted to heat. This increase is explained by the release of organic acids as a function of degradation of cell wall compounds and increased respiration. Similar results were found by Rodrigues et al. (2018), in his work with the control of soft rot in potatoes, where the control treatment had lower values of titratable acidity in relation to the treatments. The acid contents on 
the 10th day were higher than the values of the first day. From this point the values began to fall as a function of the consumption of the organic acids previously released by the metabolic processes of the tubers (YAMASHITA et al., 2006).

The $\mathrm{pH}$ did not differ between treatments. Although small variations of $\mathrm{pH}$ values are common, mainly due to variations in titratable acidity, a large amount of vegetables maintains stable pH values. (ALVARENGA et al., 2014).

\section{Conclusion}

The immersion of potatoes in the water at $40{ }^{\circ} \mathrm{C}$ was the most efficient in reducing the accurrance of soft rot, while maintaining the physico-chemical characteristics of the treated tubers during the storage period of 20 days.

The temperature of $70{ }^{\circ} \mathrm{C}$ promoted drastic physiological changes that resulted in increased susceptibility of the tubers to soft rot, as well as the acceleration of the senescence process.

\section{References}

ABBA. História da batata. 2017. Disponível em: http://www.abbabatatabrasileira.com.br/site/his toria-da-batata

AOAC. Official Methods of Analysis of AOAC International. 18. ed. Gaithersburg: AOAC, 2010.

CALBO, A.G.; NERY, A.A. Medida de firmeza em hortaliças pela técnica de aplanação. Horticultura Brasileira, v.3, p.14-18, 1995.

CHANG, D.C.; CHO, I.C.; SUH, J.T.; KIM, S.J.; LEE, Y.B. Growth and yield response of three aeroponically grown potato cultivars (Solanum tuberosum L.) to different electrical conductivities of nutrient solution. American Journal of Potato Research, v.88, n.6, p.450-458, 2011. https://doi.org/10.1007/s12230-011-9211-6

CZAJKOWSKI, R.; PEROMBELON, M.C.M.; JAFRA, S.; LOJKOWSKA, E.; POTRYKUS, M.; VAN DER WOLF, J.M. Detection, identification and differentiation of Pectobacterium and Dickeya species causing potato blackleg and tuber soft rot: A review. Annals of Applied Biology, v.166, n.1, p.18-38, 2015. https://doi.org/10.1111/aab.12166
CZAJKOWSKI, R.; PÉROMBELON, M.C.M.; VAN VEEN, J.A.; VAN DER WOLF, J.M. Control of blackleg and tuber soft rot of potato caused by Pectobacterium and Dickeya species: a review. Plant Pathology, v.60, n.6, p.999-1013, 2011. https://doi.org/10.1111/j.1365-

3059.2011.02470.x

DIAS, T.G.; BOAS, A.C.V.; JUNQUEIRA, M.B.A.; LIMA, L.C.O. Physicochemical characterization, antioxidant activity and total phenolic content in 'Gala' apples subjected to different UV-C radiation doses. Acta Scientiarum, v.39, n.1, p.67-73, 2017. https://doi.org/10.4025/actasciagron.v39i1.3097 g.

FAO. Preliminary data now available for selected countries and products. 2011. Disponível em: http://www.fao.org.

IBGE. Levantamento sistemático da produção agrícola: confronto das safras de 2015 e 2016. 2016.

JESS, S.; KILDEA, S.; MOODY, A.; RENNICK, G.; MURCHIE, A.K.; COOKE, L.R. European Union policy on pesticides: implications for agriculture in Ireland. Pest Manag. Sci, v.70 n.11, p.16461654, 2014. doi: 10.1002/ps.3801

LOVAT, C.; NASSAR, A.M.K.; KUBOW, S.; LI, X.Q.; DONNELLY, D.J. Metabolic biosynthesis of potato (Solanum tuberosum L.) antioxidant and implications for human health. Journal Critical Reviews in Food Science and Nutrition, v.56, n.14, p.2278-2303, 2015. https://doi.org/10.1080/10408398.2013.830208

MANTSEBO, C.C.; MAZARURA, U.; GOSS, M.; NGADZE, E. The epidemiology of Pectobacterium and Dickeya species and the role of calcium in postharvest soft rot infection of potato (Solanum tuberosum) caused by the pathogens: A review. African Journal of Agricultural Research, v.9, n.19, p.1509-1515, 2014. https://doi.org/10.5897/AJAR2013.8558

USALL, J.; IPPOLITO, A.; SISQUELLA, M.; NERI, F. Physical treatments to control postharvest diseases of fresh fruits and vegetables. Postharvest Biology and Technology, v.122, n.1 p.30-40,

2016. 
https://doi.org/10.1016/i.postharvbio.2016.05.00 $\underline{2}$

WALERON, M.; WALERON, K.; LOJKOWSKA, E. Occurrence of Pectobacterium wasabiae in potato field samples. European. Journal of Plant Pathology, v.137, p.149-158, 2013. https://doi.org/10.1007/s10658-013-0227-2.

ZAMBOLIM, L. Produção integrada da batata. Viçosa: Universo Agrícola, 2011. 438 p. 